\title{
Tifton grass yield on constructed wetland used for swine wastewater treatment
}

\author{
Antonio T. Matos ${ }^{1}$, Wallisson S. Freitas ${ }^{1}$, Mauro A. Martinez¹, Marcos R. Tótola² \& Aristéa A. Azevedo 3
}

\begin{abstract}
It is the purpose of this study to evaluate the agronomic behavior and yield of the Tifton 85 grass (Cynodon dactylon Pers), when used in the treatment of swine wastewater (SW ) with constructed wetland systems (CWs). For this purpose, five tanks were built measuring $24 \times 1.1 \times 0.7 \mathrm{~m}$, damp-sealed with PVC canvas and filled with $0.4 \mathrm{~m}$ crushed stone. In two of these tanks, Tifton grass was cultivated: one of the tanks (CW 3) contained the grass, and in the other (CW 4) the grass was only cultivated in the final third part of the tanks, being preceded by Alternanthera (Althernanthera philoxeroides) and cattail (Thypha latifolia L.). The SW was previously treated by means of a filtration process that consists of $0.7 \mathrm{~m}$ high organic filters; the filtering beds were made of chopped sugarcane bagasse. The filter effluents were applied to CW s at a $0.8 \mathrm{~m}^{3} \mathrm{~d}^{-1}$ flow rate, corresponding to a hydraulic detention time of about 4.8 days. During the experimental period, three cuttings were done in CW s plants in order to evaluate the dry matter yield and the nutrient extraction capacity. All plants showed satisfactory performance in dry mass yield (86.3 and 65.3 tha-1 ${ }^{-1}$, in CW 3 and CW 4 respectively) and nutrient extraction, as well as in dry matter yield. Except for the case of $\mathrm{Zn}$, the cultivation of other vegetable species in the same tank did not alter the capacity of the Tifton 85 grass extraction of the SW macro and micronutrients removal.
\end{abstract}

Key words Cynodon dactylon Pers, wetland systems, animal feed

\section{Produtividade de capim Tifton em sistema alagado construído utilizado no tratamento de águas residuárias da suinocultura}

\begin{abstract}
RESUMO
O bjetivou-se, com a realização deste trabalho, avaliar o comportamento e a produtividade do capim Tifton 85 (Cynodon dactylon Pers), quando utilizado no tratamento de água residuária da suinocultura (ARS). Para isto, foram construídos cinco tanques de 24,0 x 1,1 ×0,7 m, impermeabilizados com lona de PVC e preenchidos com uma camada de $0,4 \mathrm{~m}$ de brita zero (altura útil). Em dois tanques se cultivou o capim Titon 85; um (SAC 3) foi todo cultivado com 0 capim e 0 outro (SAC 4) o foi só no terço final, precedido pela Alternanthera e pela taboa. A ARS foi previamente tratada por filtração (filtros orgânicos de bagaço de cana-de-açúcar picado de $0,7 \mathrm{~m}$ de altura) e aplicada nos SACs, na vazão de $0,8 \mathrm{~m}^{3} \mathrm{~d}^{-1}$, com tempo de detenção hidráulica aproximado de 4,8. Realizaram-se, durante o período de experimentação, 3 cortes no capim, avaliando-se a produtividade de matéria seca e a capacidade de extração de nutrientes. 0 capim Tifton 85 apresentou produtividade acumulada de matéria seca de 86,3 tha-1 no SAC 3 e de 65,3 tha-1 no SAC 4, além de grande capacidade extratora de macro e micronutrientes. À exceção do Zn, o cultivo de outras espécies vegetais não alterou, no mesmo tanque, a capacidade do Tifton 85 em extrair macro e micronutrientes da ARS.
\end{abstract}

Palavraschave: Cynodon dactylon Pers, sistemas wetland, alimentação animal

1 DEA/U FV. CEP 36570-000, Viçosa, M G. Telephone: (31) 3899-1886. Fax: (31) 3899-2735,.E-mail: atmatos@ufv.br

2 Departamento de Microbiologia/UFV. Telephone: 3899-2968. E-mail: totola@ufv.br

3 Departamento de Biologia Vegetal/UFV. Telephone: 3899-2650. E-mail: aazevedo@ufv.br 


\section{INTRODUCTION}

Swine-culture is an important activity in Brazil. It creates lots of direct and indirect jobs, producing at the same time food with high protein value and high-quality for human consumption. Swine-culture is far more intense in southern Brazil, where its most important aspect is that related to the activities of small farmers in areas of topographic impairment for purely agricultural activities.

Swine-raising demands considerable amounts of water and, therefore, generates large volumes of wastewater that results from the cleaning of animal enclosures. The disposal of wastewater without the proper treatment into rivers and lakes causes pollution and other ecological problems, throwing the whole environment out of balance with the risk of pathogen dissemination. Should wastewater be disposed of in greater quantities, it will certainly cause serious damage to soil, plants, animals and men. There will be the danger of salinity, not to mention the harmful effects it will have on the soil's structure and its micro-porosity, contaminating plants and groundwater with heavy metals and other toxic substances (Matos et al., 1997).

There are different ways of treating wastewater with high organic matter content, such is the case of wastewater from pig raising. Among these ways, the most outstanding is that of a primary treatment followed by a secondary tertiary treatment in constructed wetland (CWs). This is the most feasible and inexpensive solution because it allows farmer to grow plants that have good commercial value and are useful to the farming activities.

In general, CWs are made up of one or more units arranged in succession or in parallel, constructed of masonry or excavated in the soil and covered with waterproof material (LDPE, HDPE or PVC 0.5 to $1.0 \mathrm{~mm}$ thick), or even clay (bentonite) compacted at the bottom of the channel (USEPA, 2000) to prevent seepage and leaching of pollutants in wastewater. On the other hand, they can be developed in monoculture with one species of emergent macrophyte, or be implemented in mixed cultivation with some selected vegetal species.

The depth of the $\mathrm{CW}$ supportive medium can range from 0.3 to $0.9 \mathrm{~m}$, depending on the depth of macrophyte roots. The bottom of the CW is likely to be steep, ranging from 0 to $2.5 \%$ following the water flow, but being perpendicular to it (Garcia et al., 2004).

The CW ecosystem is capable of cleaning, by means of physical, chemical and biological mechanisms, the water that flows through the porous medium formed in the treatment units (USEPA, 2000).

The water macrophyte, the substrate and the bacteria biofilm, which forms in the medium, are responsible, either directly or indirectly, for the removal of pollutants from wastewater, since they use the available nutrients found in the environment to support its growth. Because of this the plant being cultivated becomes the key element of CW (Brasil et al., 2007a; Fia et al., 2008).

On selecting a potential crop to be grown in CWs, the following plant characteristics should be considered: resis- tance to flooding or water saturated areas with high concentration of organic pollutants; capability of exchanging oxygen from the atmosphere on to the system; dense root system; adaptability to local climate; perennial; capacity of absorbing nutrients and generating biomass; capability of eliminating pathogens; noninvasiveness; and finally the capability of producing green mass.

Hubbard et al. (1999) evaluated the use of swine wastewater (SW) in CW. Six different species were used in the study, three of which were broadleaf (Ilex Cassine L., and L. Cephalanthus accidentalis Itea virginica $L$.) and three were lupine or narrow-leaf (Spartina patens (Ait.) Muhl, Juncus effusus L. and Panicum hemitomon Shult ('Halifax'). SW application brought about good results in the height and growth of plants; though the most significant result obtained was the production of dry mass, leaf area and the $\mathrm{N}$ and $\mathrm{P}$ concentration in plant tissue. Of the three broadleaf species, C. accidentalis had the highest dry mass production and leaf area, while among the narrow-leaf species, the ones that produced the most dry mass was the S. patens. Based on dry mass production, it was concluded that C. accidentalis and $\mathrm{S}$. patens were the best species to be used in the CWs.

The Tifton 85 (Cynodon dactylon spp.) was the species chosen for SAC cultivation because of its great feeding potential and greatest commercial value. This species is well known for its vigorous rhizomes and stolons, and flourishes in subtropical regions. It is also well known for its fast growth rate, which allows for frequent cuttings. It is perennial and adapts easily to the subhumid climatic conditions of the "Zona da Mata" of Minas Gerais and most regions of Brazil.

Given the problem created by the disposal of SW, the objective of the present study was to evaluate the agronomic performance and the nutrient extracting capability of the Tifton 85 grown in $\mathrm{CW}$ used for $\mathrm{SW}$ treatment.

\section{MATERIAL AND METHODS}

The experiment was conducted in the Experimental Area of Hydraulics, Irrigation and Drainage of the Agricultural Engineering Department of the Federal University of Viçosa - DEA/UFV, in Viçosa, Minas Gerais.

The SW used in the experiment was pumped from a $4 \mathrm{x}$ $5 \times 2 \mathrm{~m}$ brick tank utilized for collecting wastewater from the UFV poultry swine (SW) near the experimental area. Before that the SW pumping to the Experimental Plant for reuse was done by means of a system of valves and pipes for homogenization.

The experiment consisted of five wetland systems with sub-superficial, horizontal flow (CWs) used for SW treatment built in a trench excavated in the ground, measuring $0.7 \mathrm{~m}$ high (with $0.40 \mathrm{~m}$ of substrate), $1.1 \mathrm{~m}$ wide, and $24.0 \mathrm{~m}$ long. The systems were packed with a $0.5 \mathrm{~mm}$ thick geo-membrane of polyvinyl chloride (PVC). The tank bottom slope was $0.005 \mathrm{~m} \mathrm{~m}^{-1}(0.5 \%)$ and the water level was kept at the same level of the substrate at the end of CWs.

For support, gravel 0 was used, the features of which were: diameter $-\mathrm{D} 60=7.0 \mathrm{~mm}, \mathrm{CU} \mathrm{D} 60 / \mathrm{D} 10=1.6$ and a void 
volume of $48.4 \%$ and the hydraulic conductivity of the saturated medium Ks $=7970 \mathrm{~m} \mathrm{day}^{-1}$. In each application, the SW pumped up to the research area was transported into a $5,000 \mathrm{~L}$ intersection tank so as to facilitate its handling in the CWs. To proceed with the basic treatment, the wastewater was made to pass through an organic filter bed made up of chopped sugarcane bagasse before being applied to the CWs, following the recommendations by Magalhães et al. (2006). The sugar-cane bagasse was dried; ground rolled and chopped up with a $n^{\circ} 01$ Disintegrated/Chopper/Grinder (DCG). After being chopped up, the material was dried on the ground again and sieved to remove fine particles, preventing, in this way, the rapid loss of load through the filter material. After being used, the sugarcane organic material was then removed from the filter and piled up in an area near the Experimental Plant so that the composting process could be initiated. The material was then used as an organic fertilizer. The filtered SW was then conveyed into 1,000 L boxes fitted with spherical valves by means of which the flow to the $\mathrm{CW}$ could be controlled.

The tank discharge device (drainage) was made of $100 \mathrm{~mm}$ PVC pipes, drilled and fitted at the end of CW (Figure 1). Connections kept the water level in the system at the same height as that of the substrate $(0.40 \mathrm{~m})$.

The planting of the vegetable species (cattail in CW1, SAC Alternanthera in CW2, Tifton 85 in CW3 and Alternathera in the first third, followed by cattail in the second third, and the Tifton 85 in the third last part of CW4) occurred between the months of April and May 2004, with occasional water application from the dam and from the SW in order to supply the plants with water and nutrients for their development and their establishment in the CWs. The spacing between the plants was of $0.3 \mathrm{~m}$ triangular which covered the whole surface of the CWs. In December 2004, when the plant density in the tanks was adequate, the effluent from organic filters was applied daily to the CWs.

Wastewater analyses were done at the UFV Water Quality Laboratory, Department of Agricultural Engineering, UFV, following the Standard Method recommendations (APHA, 1998).

The biochemical oxygen demand $\left(\mathrm{BOD}_{5}, 20^{\circ} \mathrm{C}\right)$ was obtained by quantifying the dissolved oxygen with the iodometric method (Winkler procedure); the chemical oxygen demand (COD) with the method of chemical oxidation of open reflux; and the total Kjeldahl nitrogen (TKN) with semi-micro Kjeldahl procedure; the ammonium $\left(\mathrm{NH}_{4}{ }^{+}\right)$by using the Nessler method with subsequent quantification of the concentration by colorimetry with Hach DR/2010 spectrophotometer; and nitrate $\left(\mathrm{NO}_{3}^{-}\right)$with the method of NitraVer5 reagent (Hach) followed by the quantification of concentration by colorimetry with Hach DR/2010 spectrophotometer. After the samples were subjected to nitric-perchloric digestion, the total phosphorus concentration was determined by the spectrophotometer; the concentration of sodium and potassium was obtained by means of a flame photometer; and those of copper and zinc were detected by an atomic absorption spectrophotometer.

A daily application of $800 \mathrm{~L}$ of filtered SW (the amount produced daily by about 8 to 10 animals) was done with uniform flow rate throughout the day, which corresponded to a hydraulic detention time of approximately 4.8 days.

A.

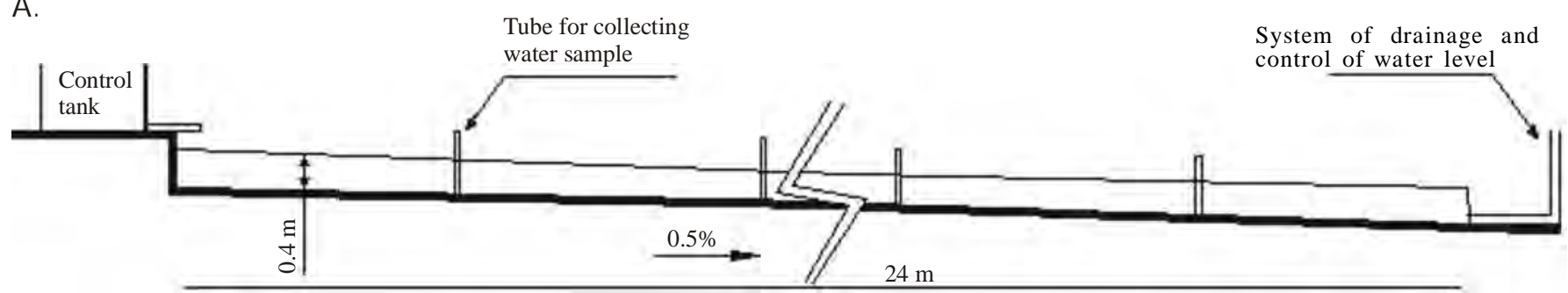

B.

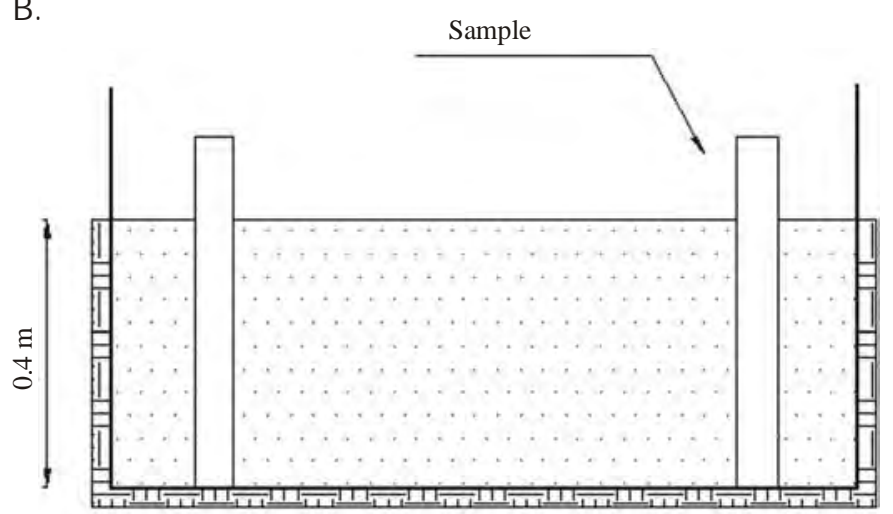

$1.09 \mathrm{~m}$

Figure 1. Longitudinal (A) and transversal (B) cross section of CW as used in the experiment 
Based on the analysis of wastewater made during the experiment, the amount applied corresponded to an average application rate of $154.8 \mathrm{~kg} \mathrm{ha}^{-1} \mathrm{day}^{-1}$ of the BOD (Table 1). This rate of application made possible the creation of effluents which, in spite of having been analyzed, are not shown or discussed in the present study.

The Tifton 85 was submitted to three cuttings in CW3 and CW4 in order to evaluate yield and nutrient content in the aerial parts of the plant samples were taken from a $4.0 \mathrm{x}$ $1.1 \mathrm{~m}$ central area in each third part of CW3 and in two areas of $2.0 \times 1.1 \mathrm{~m}$ in each third part of CW4.

The material collected was weighed in order to determine the green mass yield (GMY) by dividing the green mass produced in the area $(4.0 \times 1.1 \mathrm{~m})$. After being weighed, all the green mass for each selected area was immediately chopped, from which three samples were selected to determine the water content, making it possible to calculate the dry matter content and nutritional analysis.

Chemical analysis of the plant tissue was carried out after samples were subjected to nitric-perchloric digestion as described above. In quantifying the different forms of nitrogen, the sample was mineralized as described. Dry matter yield (DMY) was calculated ( $\mathrm{t} \mathrm{ha}^{-1}$ ) based on the value of the plant dry mass and the sampled area; whereas the plant capacity of extracting nutrients was determined by the nutrient concentration in the plant and the dry matter yield.

The samples were placed in labeled paper bags and taken to an oven with forced air circulation at a temperature of $60{ }^{\circ} \mathrm{C}$ until a constant mass (pre-drying) was obtained. Then the samples were grinded in a "Willey" grinder with a 30" mesh screen, and stored in paper bags for subsequent dry matter content measurements and nutritional analysis. The samples were then removed and taken to the oven and kept at a temperature of $105^{\circ} \mathrm{C}$ until they reached constant mass, from which the residual moisture was obtained together with dry matter for each treatment. The capacity of plants to extract nutrients was determined by the nutrient concentration in the plant and the dry matter yield.

Nutrient data in CWs 1, 2 and 3 for the three cutttings were calculated and found to match the following factorial $3 \times 3 \times 3$ (3 CWs, 3 positions in each SAC and 3 replications per position) with split plots distributed in random block design (CBD) with two factors (the CW factor and the position factor). In the event of significant effect for CWxPosition interaction in the tank, the effect of a single factor at another factor's level was correlated, and, in case there was no significant CWxPosition interaction, the factors were evaluated separately. The means of significant effects were compared by applying the Tukey test at 5\% probability. The data obtained in CW4 was taken as a descriptive analysis of extraction capacity because its way of sampling was different from the other CWs.

\section{RESULTS AND DISCUSSIONS}

The Tifton 85 adapted easily to the CWs considering the way these CWs were operated, although it took a long time to reach suitable plant density for its cultivation in this medium. Probably, this delay may have been due to the fact that both planting and crop establishment were conducted in winter.

Figure 2 presents the mean values of the dry matter content of Tifton 85 in dag $\mathrm{kg}^{-1}$, at the sample collecting places along the CWs cultivated with a single species and one with three species. However, Figure 3 shows the average values of dry matter yield in $\mathrm{t} \mathrm{ha}^{-1}$ of the Tifton 85 collected from different locations in the CWs cultivated only with a single species and one with three species.

In monoculture crop or in mixed crop, the Tifton 85 not only showed greater yield but also excellent values per cuttings - around $28.8 \mathrm{t} \mathrm{ha}^{-1}$ in monoculture, and $21.8 \mathrm{t} \mathrm{ha}^{-1}$ in the mixed crops. This grass mean yield value found in CW3 was around $86.3 \mathrm{tha}^{-1}$, and $65.3 \mathrm{t} \mathrm{ha}^{-1}$ in mixed crops. The mean yield values of Tifton 85 obtained only at a third of CW3 (85.6 t ha-1) when compared to those obtained at the end of CW4 where the same grass was grown $\left(65.3 \mathrm{tha}^{-1}\right)$, was found to decrease when other species of grass were grown in the CWs. This was due to the greater capacity of both Alternathera and cattail of extracting nutrients from wastewater, diminishing, as a result, the availability of these nutrients to the Tifton 85. Even so, the yield values obtained either from cuttings or from the values accumulated may be regarded as high, when compared to the values $17.7 \mathrm{t} \mathrm{ha}^{-1}$ obtained by Queiroz (2000) with the same grass in three

Table 1. Pollutant load applied to the eleven samples and their mean $\left(\mathrm{kg} \mathrm{ha}^{-1} \mathrm{day}^{-1}\right)^{*}$

\begin{tabular}{|c|c|c|c|c|c|c|c|c|c|c|c|c|}
\hline & \multicolumn{12}{|c|}{ Nutrient loads (kg ha ${ }^{-1}$ day $^{-1}$ ) Sample } \\
\hline & $1^{a}$ & $2^{a}$ & $3^{a}$ & $4^{a}$ & $5^{a}$ & $6^{a}$ & $7^{a}$ & $8^{a}$ & $9^{a}$ & $10^{a}$ & $11^{a}$ & \\
\hline & $17 / 02$ & $14 / 03$ & $29 / 03$ & $05 / 05$ & $18 / 05$ & $01 / 06$ & $16 / 06$ & 04/07 & $18 / 07$ & $16 / 08$ & $01 / 09$ & IVIedia \\
\hline COD & 233.2 & 561.5 & 649.6 & 135.2 & 808.1 & 1008.1 & 1331.1 & 350.6 & 544.6 & 473.3 & 404.4 & 590.9 \\
\hline BOD & - & 175.2 & 159.0 & 38.7 & 169.1 & 167.9 & 354.2 & 86.5 & 183.8 & 128.8 & 84.4 & 154.8 \\
\hline TKN & 72.7 & 50.1 & 89.5 & 65.2 & 113.7 & 124.4 & 113.9 & 101.5 & 109.0 & 85.4 & 101.1 & 93.3 \\
\hline Ammonium & 65.2 & 21.4 & 12.6 & 66.2 & 76.7 & 76.0 & 85.2 & 87.9 & 65.5 & 55.9 & 94.7 & 67.0 \\
\hline Nitrate & 0.49 & 0.24 & 1.02 & 2.56 & 0.09 & 0.16 & 0.11 & 0.14 & 0.10 & 0.13 & 0.12 & 0.47 \\
\hline P-total & 10.5 & 13.4 & 24.2 & 15.2 & 26.3 & 33.8 & 28.9 & 21.4 & 26.7 & 21.4 & 21.7 & 22.1 \\
\hline K & 17.3 & 18.5 & 25.9 & 27.6 & 38.7 & 41.7 & 56.2 & 42.3 & 50.2 & 37.1 & 43.6 & 36.3 \\
\hline $\mathrm{Na}$ & 5.91 & 6.12 & 7.21 & 9.33 & 13.4 & 14.4 & 15.3 & 12.5 & 14.7 & 12.1 & 13.9 & 11.3 \\
\hline $\mathrm{Cu}$ & 0.04 & 0.16 & 0.28 & 0.10 & 0.16 & 0.56 & 0.22 & 0.03 & 0.35 & 0.50 & 0.32 & 0.25 \\
\hline $\mathrm{Zn}$ & 0.03 & 2.22 & 3.16 & 0.02 & 2.49 & 2.61 & 2.22 & 0.63 & 2.04 & 1.01 & 0.94 & 1.58 \\
\hline
\end{tabular}

* Values based on the mean of the samples collected from the effluent points to the organic filter (CWs effluents) 


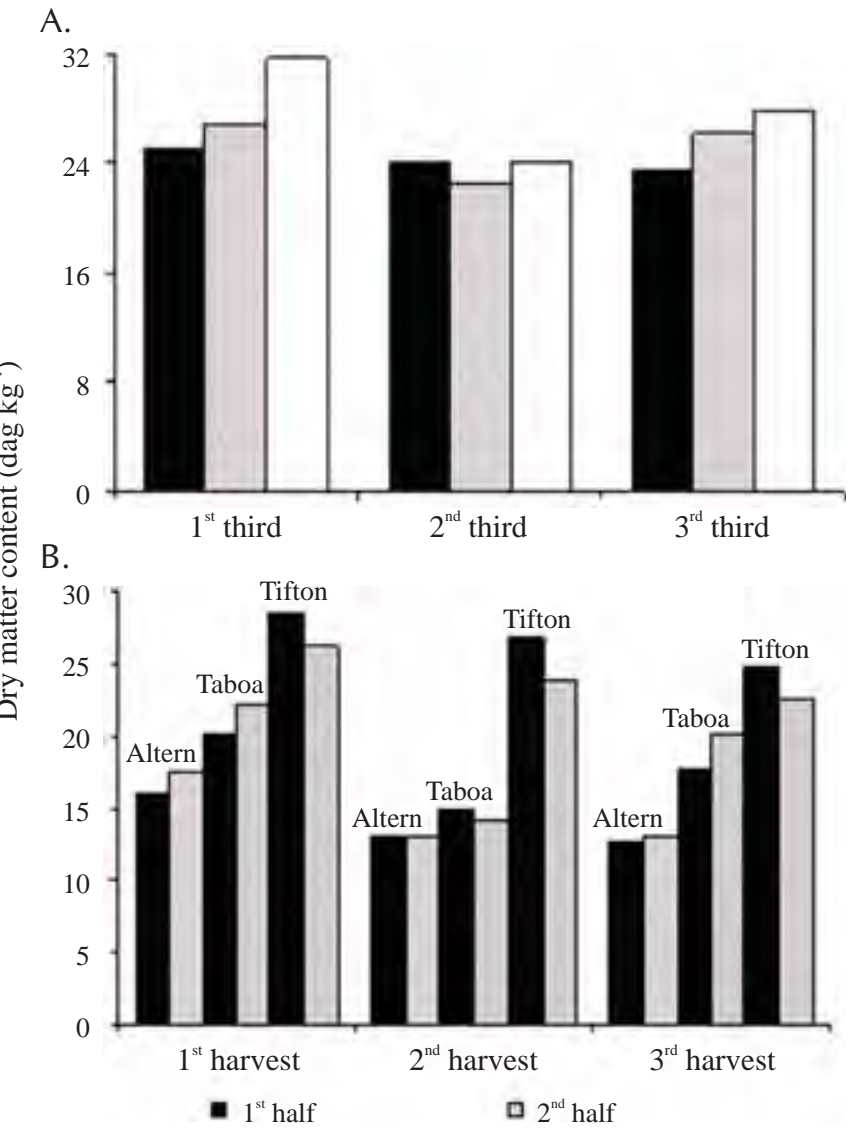

Figure 2. M ean values of dry matter content in the Tifton 85 collected from different places along the length of CW s cultivated with a single species (A) and with three species (B)

cuttings after a four-month period of SW fertigation.

Tables 2 and 3 present, respectively, the mean values in $\mathrm{kg} \mathrm{ha}^{-1}$, of the extraction of total nitrogen, ammonium, nitrate, total phosphorus, potassium, sodium, copper and zinc obtained from the yield and from the concentration of these nutrients in the dry matter produced as a result of monoculture or mixed culture along the three cuttings done in different sampling positions in the tanks.

There was no significant difference in the extraction values of $\mathrm{N}_{\text {total }}$ obtained in the $1^{\text {st }}$ and $3^{\text {rd }}$ cuttings along CW3. As the plant used this nutrient without affecting yield, this is not seen as a limiting factor for its development.

The cumulative yield of N-total obtained in the present experiment (2,043 $\mathrm{kg} \mathrm{ha}^{-1}$ in three cuttings) was much higher than that cited by Hunt et al. (1999), in the U.S. They found in CWs of 3.6 x $33.5 \mathrm{~m}$, extraction of $428 \mathrm{~kg} \mathrm{ha}^{-1} \mathrm{day}^{-1}$ in the CW with mixed crops of Typha and Sparganium americanum

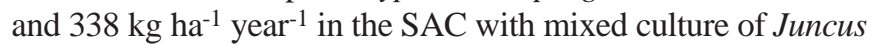
effusus and the species Scipus under treatment with SW at an average of $3 \mathrm{~kg} \mathrm{ha}^{-1}$ day $^{-1}$ of N-total; however, the accumulated extractions obtained, on being added to the values of the three cuttings, overcame by $552 \mathrm{~kg} \mathrm{ha}^{-1}$ (3,454 $\mathrm{kg} \mathrm{ha}^{-1}$ total protein) as examined by Queiroz (2000) in soil fertigated with SW at an average volume of $187 \mathrm{~kg} \mathrm{ha}^{-1}$ day $^{-1}$ of N-Total during a 4month trial and for three equal cuttings.

Considering the quality of the grass produced, the author found crude protein values between 19.2 and $19.3 \mathrm{dag} \mathrm{kg}^{-1}$;

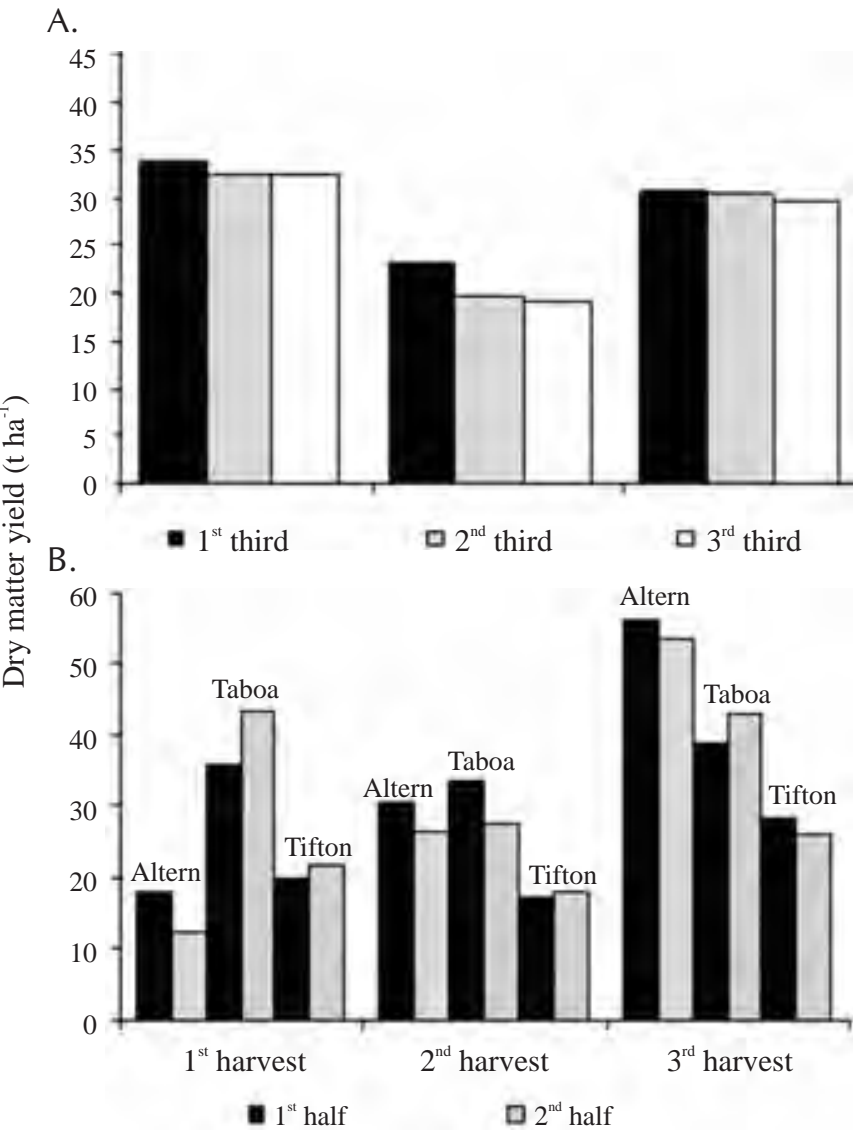

Figure 3. Mean values of dry matter yield from collecting places al ong the length of the CW cultivated with only Tifton $85(\mathrm{~A})$ and mixed species (B)

Table 2. Mean values of nutrient extraction in $\mathrm{kg} \mathrm{ha}^{-1}$, based on nutritional analysis and dry matter yield obtained in three cuttings done at three sampling places in tanks cultivated with only Tifton 85

\begin{tabular}{|c|c|c|c|c|}
\hline & Cutting & $1^{\text {st }}$ third & $2^{\text {nd }}$ third & $3^{\text {rd }}$ third \\
\hline \multirow{3}{*}{$\mathrm{N}$-total } & $1^{0}$ & $963 \mathrm{a}$ & $704 \mathrm{a}$ & $741 \mathrm{a}$ \\
\hline & $2^{0}$ & 669 & 610 & 557 \\
\hline & $3^{0}$ & 669 a & $633 \mathrm{a}$ & $586 \mathrm{a}$ \\
\hline \multirow{3}{*}{$\mathrm{NH}_{4}^{+}$} & $1^{0}$ & $1067 \mathrm{a}$ & $648 \mathrm{~b}$ & $504 \mathrm{~b}$ \\
\hline & $2^{0}$ & $508 \mathrm{ab}$ & $473 a b$ & $398 \mathrm{~b}$ \\
\hline & $3^{0}$ & 578 & 443 & 444 \\
\hline \multirow{3}{*}{$\mathrm{NO}_{3}^{-}$} & $1^{0}$ & $78.3 \mathrm{a}$ & $33.5 \mathrm{~b}$ & $0,0 \mathrm{c}$ \\
\hline & $2^{0}$ & $8.0 \mathrm{a}$ & 26.7 a & $23.3 \mathrm{a}$ \\
\hline & $3^{0}$ & 47.7 & 37.2 & 17.0 \\
\hline \multirow{3}{*}{ P-total } & $1^{0}$ & 154 & 114 & 91 \\
\hline & $2^{0}$ & $102 \mathrm{a}$ & $86 \mathrm{~b}$ & $83 \mathrm{~b}$ \\
\hline & $3^{0}$ & 125 & 107 & 103 \\
\hline \multirow{3}{*}{ K } & $1^{0}$ & $870 \mathrm{a}$ & $595 \mathrm{~b}$ & $462 \mathrm{~b}$ \\
\hline & $2^{0}$ & 582 & 533 & 539 \\
\hline & $3^{0}$ & 563 & 566 & 607 \\
\hline \multirow{3}{*}{$\mathrm{Na}$} & $1^{0}$ & $11 \mathrm{a}$ & $10 \mathrm{a}$ & $9 \mathrm{a}$ \\
\hline & $2^{0}$ & $13 \mathrm{a}$ & $7 a b$ & $8 \mathrm{ab}$ \\
\hline & $3^{0}$ & 4 & 4 & 7 \\
\hline \multirow{2}{*}{$\mathrm{Cu}$} & $1^{0}$ & 311 & 246 & 233 \\
\hline & $2^{0}$ & 153 & 136 & 90 \\
\hline \multirow{3}{*}{$\mathrm{Zn}$} & $1^{0}$ & $7,520 \mathrm{a}$ & $5,264 \mathrm{~b}$ & $1,883 \mathrm{c}$ \\
\hline & $2^{0}$ & $8,488 \mathrm{a}$ & $6,159 \mathrm{~b}$ & $2,745 \mathrm{c}$ \\
\hline & $3^{0}$ & $6,213 a$ & $5,343 \mathrm{a}$ & $3,970 \mathrm{a}$ \\
\hline
\end{tabular}

Within a row, in the same cutting means with the same letter do not differ at $0.05 \%$ probability level according to the Tukey test 
Table 3. M ean values of nutrient extraction in $\mathrm{kg} \mathrm{ha}^{-1}$, based on nutritional analysis and dry matter yield in three cutting done in both Tifton 85 sample collecting positions in mixed crop tanks

\begin{tabular}{|c|c|c|c|}
\hline & Cutting & $1^{\text {st }}$ half & $2^{\text {nd }}$ half \\
\hline \multirow{3}{*}{$\mathrm{N}$-total } & $1^{0}$ & 488 & 509 \\
\hline & $2^{0}$ & 490 & 597 \\
\hline & $3^{0}$ & 570 & 540 \\
\hline \multirow{3}{*}{$\mathrm{NH}_{4}^{+}$} & $1^{0}$ & 440 & 602 \\
\hline & $2^{0}$ & 377 & 463 \\
\hline & $3^{0}$ & 435 & 436 \\
\hline \multirow{3}{*}{$\mathrm{NO}_{3}^{-}$} & $1^{0}$ & N.D. & N.D. \\
\hline & $2^{0}$ & 2.2 & N.D. \\
\hline & $3^{0}$ & 12.3 & 7.2 \\
\hline \multirow{3}{*}{ P-total } & $1^{0}$ & 74 & 80 \\
\hline & $2^{0}$ & 69 & 78 \\
\hline & $3^{0}$ & 98 & 100 \\
\hline \multirow{3}{*}{$\mathrm{K}$} & $1^{0}$ & 331 & 405 \\
\hline & $2^{0}$ & 311 & 309 \\
\hline & $3^{0}$ & 456 & 444 \\
\hline \multirow{3}{*}{$\mathrm{Na}$} & $1^{0}$ & 4.7 & 6.3 \\
\hline & $2^{0}$ & 5.3 & 6.1 \\
\hline & $3^{0}$ & 4.3 & 5.6 \\
\hline \multirow{2}{*}{$\mathrm{Cu}$} & $1^{0}$ & 180 & 315 \\
\hline & $2^{0}$ & 37 & 41 \\
\hline \multirow{3}{*}{$\mathrm{Zn}$} & $1^{0}$ & 768 & 1,261 \\
\hline & $2^{0}$ & 1,038 & 1,044 \\
\hline & $3^{0}$ & 1,017 & 840 \\
\hline
\end{tabular}

Within row in the same cuttings, means with the same letter do not differ from each other at $0.05 \%$ probability level as observed with Tukey test

whereas, in the present experiment, the values obtained varied from 12.8 to $19.1 \mathrm{dag} \mathrm{kg}^{-1}$ in $\mathrm{CW} 3$ and 12.5 to 19.4 dag $\mathrm{kg}^{-1}$ in CW4.

Analyzing the effect of the sample position in the CWs, it was observed that higher values of ammonium extraction were obtained during the $1^{\text {st }}$ third of the CWs, though such trend was not significant in all cuttings.

Higher nitrate extraction values were observed in the $1^{\text {st }}$ third and in the $1^{\text {st }}$ cutting; these results demonstrated that in the initial phase of CW operation, the plants placed in the fore part of the CW had a larger quantity of nitrate to be absorbed. With an increase of the operating time, greater amount of total-N was accumulated in the system, making a greater amount of nitrate available along the entire CW, which made anion to be better absorbed.

Greater extraction of P occurred in the $1^{\text {st }}$ third of the CWs; however, only in the $2^{\text {nd }}$ cutting, significant differences occurred among all the extractions of total-P regarding the position of the plants in the CW. P being a chemical element strongly associated to organic matter, the largest retention of solid material in the initial third of the CWs made it possible for greater availability of nutrients to the plants to occur.

The cumulative extraction of $\mathrm{P}$ was $322 \mathrm{~kg} \mathrm{ha}^{-1}$ - significantly higher than that of $61 \mathrm{~kg} \mathrm{ha}^{-1}$ - obtained by Queiroz et al. (2004), with the Tifton fertigated with SW at a load of $91 \mathrm{~kg} \mathrm{day}^{-1}$ of $\mathrm{P}$, during 4-month experimentation.

Taking as reference the position of the samples collected from the grass in CW1 in the first cutting, the highest Kextraction was observed to occur in the $1^{\text {st }}$ third of the tanks.
The K cumulative production obtained with Tifton 85 was of $1,772 \mathrm{~kg} \mathrm{ha}^{-1}$, a value three times higher than that of $591 \mathrm{~kg} \mathrm{ha}^{-1}$ obtained by Queiroz et al. (2004) in soil fertigated with SW with a load of $91 \mathrm{~kg} \mathrm{ha}^{-1}$ day-1 $^{-1}$ of $\mathrm{K}$ during 4-month experimentation. On average, the extractions of $\mathrm{Na}$ by the plants were relatively well distributed throughout the length of the tank, much in the same way as it happened in $\mathrm{K}$.

The cumulative absorption of $\mathrm{Na}$ by Tifton 85 was $25 \mathrm{~kg} \mathrm{ha}^{-1}$; equally higher than the $6.6 \mathrm{~kg} \mathrm{ha}^{-1}$ obtained by Queiroz et al. (2004) in soil fertigated with SW applied in loads of $15 \mathrm{~kg} \mathrm{ha}^{-1} \mathrm{day}^{-1}$ of $\mathrm{Na}$, during 4-month experimentation.

Cu extractions obtained from the Tifton 85 (389 $\mathrm{g} \mathrm{ha}^{-1}$ in just two cuttins) exceeded $180 \mathrm{~g} \mathrm{ha}^{-1}$ as obtained by Queiroz et al. (2004) in soil fertilized with SW applied in loads of $1.2 \mathrm{~kg} \mathrm{ha}^{-1}$ day $^{-1}$ of $\mathrm{Cu}$, during 4-month experimentation. $\mathrm{Cu}$ extraction which, at first may seem to have been small, was similar to that reported by Lim et al. (2001) in experiments with cultivated (cattail), and non-cultivated CWs when considering that less than $1 \%$ of the copper that was applied to the SACs by wastewater was extracted by the cattail. The strong complexation/chelation of $\mathrm{Cu}$ in organic material (Queiroz et al., 2004) resulted in lower availability of this nutrient to be absorbed; therefore, its extraction is much less compared to the removal capacity of the system.

It was observed in the first and second cuttings that larger Zn extractions occurred in the first third of the tank; the occurrence of $\mathrm{Zn}$ at the beginning of CWs was due to some greater retention of organic material contained in the SW as shown by the results.

Zn cumulative production was $15.9 \mathrm{~kg} \mathrm{ha}^{-1}$ : a value ten times as high as that obtained by Queiroz et al. (2004) when fertigated with SW in loads of $14.5 \mathrm{~kg} \mathrm{ha}^{-1}$ day $^{-1}$ of Zn during a 4-month experimentation in an area cultivated with Tifton 85, the results of which, as shown in the present work, were due to both an increased yield and the highest $\mathrm{Zn}$ content found in the dry matter.

By means of a comparative analysis between the extraction data obtained in the $3^{\text {rd }}$ last part of CW3 and those obtained in the final third of CW4, both cultivated with Tifton85, similarities between the results have been verified, except for those obtained from zinc extraction, which exhibited a far more apparent effect. As some lower $\mathrm{Zn}$ extraction was obtained in CW4, it is believed that the extracting capacity and/or the environmental conditions provided by Alternathera and the cattail decreased more significantly the availability of this nutrient for the Tifton 85. Where the other nutrients are concerned, the Alternanthera and the cattail did not affect environmental conditions or the composition of wastewater to the point of preventing its absorption by the grass. These results were far from being unexpected; considering that, due to the environment strong oxygen absorption capacity provided by the cattail, as observed by many researchers (Brasil et al. 2007b, Fia et al., 2008), one would expect greater nitrate absorption, at the expense of ammonium absorption and other nutrients by the plants, to occur by means of SW organic material oxidation. 


\section{CONCLUSIONS}

1. The grass adapted well to flooding conditions and to higher organic loads, exhibiting good agronomic performance in terms of yields (86.3 $\mathrm{tha}^{-1}$ of dry matter in CW3 and $65.3 \mathrm{t} \mathrm{ha}^{-1}$ in CW4) and extraction of macro and micro nutrients.

2. The nutrient cumulative yield of the grass grown in the CWs exceeded that obtained by other researchers with the same grass.

3. The introduction of Alternanthera and cattail as a way of securing previous treatment for the SW in the tanks, failed to impart the Tifton-85 better agronomic performance, and in the case of $\mathrm{Zn}$, it decreased its absorption.

\section{LITERATURE CITED}

APHA - American Public Health Association. Standard methods for the examination of water and wastewater. 20 ed. New York: AWWA/APHA/WEF. 1998. 1154p.

Brasil, M. S.; Matos, A. T.; Fia, R.; Silva, N. C. Desempenho agronômico de vegetais cultivados em sistemas alagados utilizados no tratamento de águas residuárias da suinocultura. Engenharia na Agricultura. v.15, n.3, p.307-315, 2007 a.

Brasil, M. S.; Matos, A. T.; Silva, C. M.; Cecon, P. R.; Soares, A. A. Modelling of pollution removal in constructed wetlands with horizontal subsurface flow. Agricultural Engineering Research. v.13, n.2007, p.48-56, 2007b.

Fia, R.; Matos, A. T.; Ferreira, P. A.; Teodoro, P. E. P.; Schuery, F. C.; Luiz, F. A. R. Desempenho agronômico da Thypha sp. e Alternanthera philoxeroides Mart utilizadas no tratamento de águas residuárias da lavagem e descascament/despolpa dos frutos do cafeeiro em sistema alagado construído. Engenharia na Agricultura, v.16, n.4, p.436-448, 2008.
Garcia, J.; Aguirre, P.; Mujerriego, R.; Huang, Y.; Ortiz, L.; Bayona, J. M. Initial contaminant removal performance factors in horizontal flor reed beds used for treating urban wastewater. Water Research, v.38, p.1669-1678, 2004.

Hubbard, R. K.; Ruter, J. M.; Newton, G. L.; Davis, J. G. Nutrient uptake and growth response of six wetland/riparian plant species receiving swine lagoon effluent. Transaction of the ASAE, v.42, n.5, p.1331-1341, 1999.

Hunt, P. G.; Szögi, A. A.; Humenik, F. J.; Rice, J. M. Treatment of animal wastewater in constructed wetlands. In: $8^{\text {th }}$ International Conference on Network of Recycling of Agricultural. Municipal and Industrial Residues in Agriculture. Rennes. 1998. Proceedings... Rennes: FAO ESCORENA. 1999. p.305-313.

Lim, P. E.; Wong, T. F.; Lim, D. V. Oxygen demand. nitrogen and copper removal by free-water-surface and subsurface-flow constructed wetlands under tropical conditions. Environment International, v.26, n.5-6, p.425-431, 2001.

Magalhães, M. A.; Matos, A. T.; Deniculi, W.; Tinoco, I. F. F. Operação de filtros orgânicos utilizados no tratamento de águas residuárias de suinocultura. Revista Brasileira de Engenharia Agrícola e Ambiental, v.10, n.2, p.472-478, 2006.

Matos, A. T.; Sediyama, M. A. N.; Freitas, S. P.; Vidigal, S. M.; Garcia, N. C. P. Características químicas e microbiológicas do solo influenciadas pela aplicação de dejeto líquido de suínos. Revista Ceres, v.44, n.254, p.399-410, 1997.

Queiroz, F. M. de. Avaliação de gramíneas forrageiras para o tratamento de águas residuárias de suinocultura. Viçosa: UFV. 2000. 61p. Tese Doutorado

Queiroz, F. M.; Matos, A. T.; Pereira, O. G.; Oliveira, R. A.; Lemos, A. L. Características químicas do solo e absorção de nutrientes por gramíneas em rampas de tratamento de águas residuárias da suinocultura. Revista Engenharia na Agricultura, v.12, n.2, p.77-90, 2004.

USEPA - United States Environmental Protection Agency. Wastewater technology fact sheet wetlands: subsurface flow. EPA 832F-00-023.Washington.September.2000. http://www.epa.gov/ owow/wetlands/pdf/design.pdf > 09 Out. 2003 